\title{
Comparison of formaldehyde and methanol fixatives used in the detection of ion channel proteins in isolated rat ventricular myocytes by immunofluorescence labelling and confocal microscopy
}

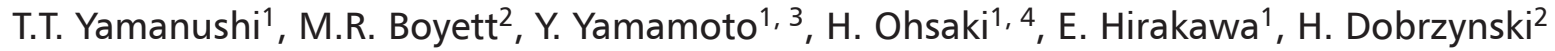 \\ ${ }^{1}$ Kagawa Prefectural University of Health Sciences, 281-1 Hara, Mure-cho, Takamatsu City, Kagawa, Japan \\ ${ }^{2}$ Cardiovascular Medicine, Faculty of Medical and Human Sciences, University of Manchester, Manchester, United Kingdom \\ ${ }^{3}$ Human Health Sciences, Faculty of Medicine, Kyoto University, Yoshida-Konoe-cho, Sakyo-ku, Kyoto, Japan \\ ${ }^{4}$ Department of Medical Technology, Faculty of Health Sciences, Ehime Prefectural University of Health Sciences, \\ 543 Takoda, Tobe-cho, lyo-gun, Ehime, Japan
}

[Received 23 July 2014; Accepted 13 October 2014]

In this study, a fixation protocol using a 10\% neutral buffered formalin (FA) solution and another protocol using a methanol $(\mathrm{MeOH})$ solution were compared for detection of ion channels, $K_{v} 1.5, K_{v} 4.2, \mathrm{Ca}_{v} 1.2, \mathrm{~K}_{i r} 6.2, \mathrm{Na}_{v} 1.5$ and $\mathrm{Na}_{v} 1.1$ in rat myocytes by immunolabelling. $K_{v} 1.5$ and $K_{v} 4.2$ at intercalated discs and $\mathrm{Ca}_{v} 1.2$ at transverse tubules were not detected by FA but were detected by MeOH. $\mathrm{K}_{i r} 6.2$ at transverse tubules and $\mathrm{Na}_{v} 1.5$ at sarcolemma were detected by FA but not by $\mathrm{MeOH}$. It is suggested that both FA and MeOH fixation protocols should be used for the detection of cardiac ion channels by immunolabelling. (Folia Morphol 2015; 74, 2: 258-261)

Key words: heart, immunocytochemistry, fixation, cross-linker, coagulant, formalin

\section{INTRODUCTION}

lon channels are pore-forming membrane proteins that span the lipid bilayer to allow a highly selective pathway into the cell [10]. The opening of ion channels allows the movement of ions across the cell membrane and can lead to a depolarisation of the cell from its negative resting membrane potential. The cardiac action potential consists of distinct phases of depolarisation and repolarisation brought about by the opening and closing of specific ion channels. The cloning and sequencing of ion channel proteins has allowed the investigation of cardiac ion channels at the molecular level [10]. Immunolabelling of ion channels in the heart is one of the most powerful tools for understanding their localisation within myocytes [2]. Despite the importance of immunolabelling, however, ion channel proteins in cardiac myocytes are sometimes difficult to detect using the immunofluorescence labelling technique.

The initial fixation of the tissue is an essential step in the immunolabelling protocol. The optimal fixation conditions for immunolabelling are a balance between the preservation of tissue morphology, the immobilisation of antigens, the preservation of antigen immunoreactivity, and the adequate penetrability of tissue by reagents [5]. The fixation of the tissue often leads to the introduction of artefacts [4], alterations in the chemical composition of the tissue, and physical changes in cellular and extracellular constituents. Two common types of fixatives are cross-linkers and coagulants. Cross-link fixatives such as formaldehyde, paraformaldehyde and

Address for correspondence: Dr T.T. Yamanushi, Kagawa Prefectural University of Health Sciences, 281-1 Hara, Mure-cho, Takamatsu City, Kagawa 761-0123, Japan, tel: +81-87-870-1212, fax: +81-87-870-1202, e-mail: t.t.yamanushi@chs.pref.kagawa.jp 
Table 1. Immunolabelling detection of ion channels with $10 \%$ neutral buffered formalin (FA) or methanol (MeOH) fixation protocol

\begin{tabular}{|c|c|c|c|c|c|c|c|c|c|c|c|c|c|c|c|c|c|c|}
\hline & \multicolumn{3}{|c|}{ Kv1.5 } & \multicolumn{3}{|c|}{ Kv4.2 } & \multicolumn{3}{|c|}{ Cav1.2 } & \multicolumn{3}{|c|}{ Kir6.2 } & \multicolumn{3}{|c|}{ Nav1.5 } & \multicolumn{3}{|c|}{ Nav1.1 } \\
\hline & $\mathbf{T}$ & ID & $S$ & $\mathbf{T}$ & ID & $S$ & $\mathbf{T}$ & ID & $S$ & $\mathbf{T}$ & ID & $S$ & $\mathbf{T}$ & ID & $S$ & $\mathbf{T}$ & ID & $S$ \\
\hline FA fixation & + & - & - & + & - & - & - & - & + & + & - & - & + & + & + & + & - & + \\
\hline $\mathrm{MeOH}$ fixation & + & + & - & + & + & - & + & - & - & - & - & - & + & + & - & + & - & + \\
\hline
\end{tabular}

+ presence of labelling; - absence of labelling; $\mathrm{T}-\mathrm{t}$-tubules; ID - intercalated discs; $S$ - sarcolemma

glutaraldehyde are the most commonly used fixatives for immunolabelling because of their high degree of tissue/cell penetration and good morphological preservation [4]. The mechanism of fixation by cross-linkers is to form methylene bridges $\left(-\mathrm{CH}_{2}-\right)$ between lysine and glutamine amino acids on protein chains, which leads to the immobilisation of the proteins [7]. The simplest cross-linker, formaldehyde $\left(\mathrm{CH}_{2} \mathrm{O}\right)$, is present in a hydrated form, methylene glycol $\left(\mathrm{OH}-\mathrm{CH}_{2}-\mathrm{OH}\right)$, in solution. Condensing of the methylol group $\left(\mathrm{CH}_{2} \mathrm{OH}\right)$ with another compound containing active hydrogen ions leads to the production of the cross-links. The most common formaldehyde-based fixative is neutral buffered formalin (FA) solution, which was used in this study and is referred to here as FA (formalin is an aqueous solution of formaldehyde). Examples of coagulant fixatives are acetone and alcohols such as ethanol and methanol (MeOH) [13]. Because alcohols fix through coagulation without forming additive compounds, they permit good antibody penetration and do not block immunoreactive determinants [13]. They are particularly useful for surface membrane antigens, which often display carbohydrate-containing epitopes; however, conformational changes can occur. Acetone is an excellent preservative of immunoreactive sites, leaving most sites intact, but as it is also a very poor penetrator, fixation is not complete and extended incubation may result in chromatolysis and membrane loss [4].

FA is the most commonly used fixative for detecting ion channel proteins in cardiac myocytes using immunolabelling techniques, but the effects of coagulants on cardiac myocytes are not fully understood. The purpose of the present study was to compare fixation with $\mathrm{FA}$ and fixation with $\mathrm{MeOH}$ to obtain an optimal immunolabelling of ion channel proteins in cardiac cells.

\section{MATERIALS AND METHODS}

\section{Materials and antibodies}

All chemicals were purchased from Sigma-Aldrich Co. (St. Louis, MO), unless otherwise specified. All primary antibodies (immunoglobulin G [lgG]) were raised against intracellular epitopes. The primary lgGs investigated in this study were polyclonal lgGs raised against ion channels (Alomone Labs Ltd., Jerusalem, Israel) (Table 1). Secondary lgGs conjugated to fluorescein isothiocyanate (FITC) were purchased from Chemicon International Inc. (Temecula, CA). All IgGs were diluted to 1 in 100 in phosphate buffered saline (PBS) containing $1 \%$ bovine serum albumin (BSA) before use.

\section{Ventricular myocyte preparation}

Sprague-Dawley male rats (300-800 g) were killed by stunning and cervical dislocation in accordance with the UK Animals (Scientific Procedures) Act 1986. Ventricular myocytes were enzymatically isolated and prepared as described previously [12]. After isolation, ventricular myocytes were suspended in Tyrode solution (in $\mathrm{mM}$ : $\mathrm{NaCl}, 130 ; \mathrm{KCl}, 5.4 ; \mathrm{MgCl}_{2}, 1.4 ; \mathrm{CaCl}_{2}$, $0.5 ; \mathrm{NaH}_{2} \mathrm{PO}_{4}, 0.4$; glucose, 10; taurine, 20; creatine, 10; HEPES, 5; pH 7.3 with $\mathrm{NaOH}$ ), placed onto Super-frost Plus slides, and left at room temperature for $30 \mathrm{~min}$ for the cells to attach to the glass slides.

\section{FA fixation protocol}

Myocytes were incubated with FA (a phosphate buffered $10 \%$ formalin [approximately $4 \%$ formaldehyde] solution, $\mathrm{pH}$ 6.8-7.2) for $30 \mathrm{~min}$ at room temperature as previously described [2], followed by $0.1 \%$ Triton $\mathrm{X}-100$ in PBS for 30 min to permeabilise the cell membrane.

\section{MeOH fixation protocol}

$\mathrm{MeOH}$ was pre-cooled to $-20^{\circ} \mathrm{C}$ prior to the incubation of myocytes at room temperature for $5 \mathrm{~min}$, which fixes and permeabilises the cell membrane [13].

\section{Immunofluorescent labelling}

After fixation and permeabilisation, immunofluorescent labelling was performed as described previously [14]. After fixation and permeabilisation, myocytes were washed in $0.01 \mathrm{M} \mathrm{PBS}(\mathrm{pH} 7.4)$ and blocked with $10 \%$ donkey serum in PBS. To prevent non-specific labelling, all primary and secondary 

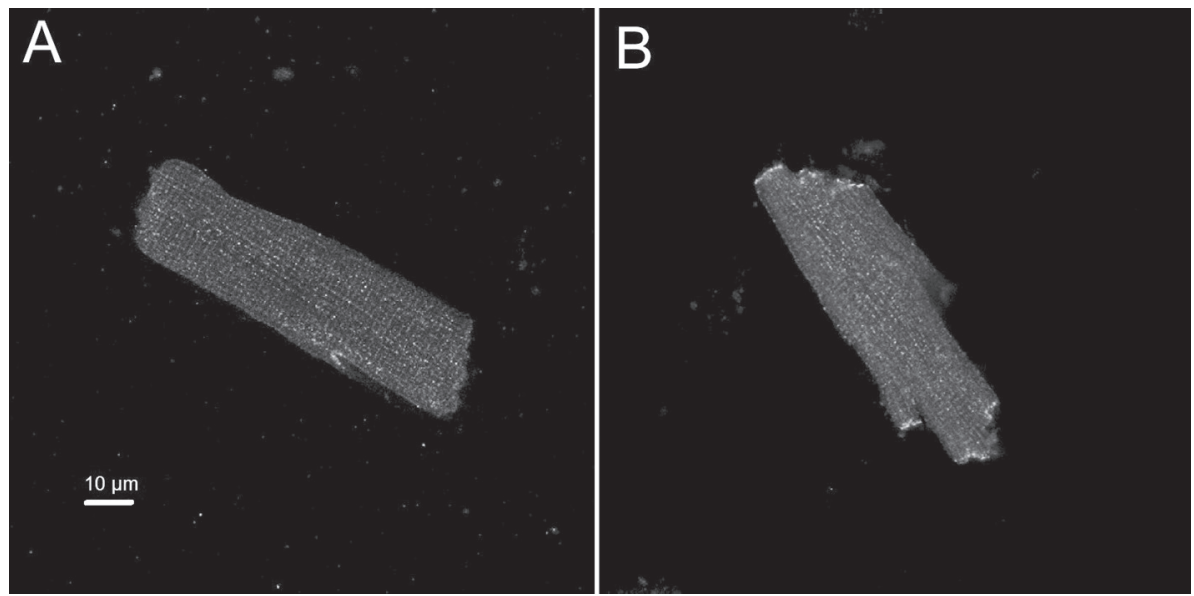

Figure 1. Images of immunolabelling of $\mathrm{K}_{v} 1.5$ in rat ventricular myocytes; $A$. Myocytes were fixed with $10 \%$ neutral buffered formalin (FA) for $30 \mathrm{~min}$ at room temperature; B. Myocytes were fixed with pre-cooled methanol $(\mathrm{MeOH})$ for $5 \mathrm{~min}$ at room temperature. Scale bar $=10 \mu \mathrm{m}$.

antibodies were diluted with PBS containing $1 \%$ BSA. Myocytes were incubated with primary lgGs at $4^{\circ} \mathrm{C}$ overnight and then incubated with secondary lgGs conjugated with FITC at room temperature for $1 \mathrm{~h}$. Before and after incubation with secondary lgGs, the myocytes were washed with PBS. Finally, the myocytes were mounted with Vectashield mounting media (Vector Laboratories, Burlingame, CA), and the cover-slips were sealed with nail polish. Sample slides were stored in the dark at $4^{\circ} \mathrm{C}$ for up to 1 week before observation.

\section{Observation with confocal microscopy}

Immunofluorescent labelling of all proteins was visualised using laser scanning confocal microscopes (TCS SP [Leica Microsystems, Heidelberg, Germany], LSM 5 [Carl Zeiss, Oberkochen, Germany], or Radiance 2100 MP Rainbow [Bio-Rad, Philadelphia, PA]: made available by the Division of Research Instrument and Equipment, Life Science Research Centre, Kagawa University) to detect FITC signals. Images were collected from a single optical slice through the centre of each myocyte. More than 10 cells were observed from 3 hearts for each protein investigated and at least 3 typical images (i.e., from 3 cells for each protein investigated) were saved for labelling analysis. No labelling was detectable without either the primary or secondary lgGs.

\section{RESULTS AND DISCUSSION}

Differences were found in terms of the expression pattern for ion channels with different fixation protocols (Table 1). One example image, the immunolabel- ling of the $\mathrm{K}_{\mathrm{v}} 1.5$ channel, is shown in Figure 1. $\mathrm{K}_{\mathrm{v}} 1.5$ is responsible for the ultra-rapid delayed rectifier $\mathrm{K}^{+}$current, $\mathrm{I}_{\mathrm{Kur}}[10] . \mathrm{K}_{\mathrm{v}} 1.5$ labelling was detected as a transversely striated pattern with FA (Fig. 1A) and $\mathrm{MeOH}$ (Fig. 1B). In this study, the transversely striated labelling pattern corresponded to transverse tubules (t-tubules) probably because of the similar labelling pattern as the marker of t-tubules, $\alpha$-actinin [15]. $\mathrm{K}_{\mathrm{v}} 1.5$ labelling at the intercalated discs (IDs) was detected with $\mathrm{MeOH}$ (Fig. 1B) but not with FA (Fig. 1A). The $K_{v} 1.5$ channel has been shown to be located at the IDs of atrial cells when visualised with $\mathrm{MeOH}$ fixation [3]. Regarding other results using FA and $\mathrm{MeOH}$ fixation (Table 1), $\mathrm{K}_{\mathrm{v}} 4.2$ at the IDs and $\mathrm{Ca}_{\mathrm{v}} 1.2$ at the t-tubules were not detected by FA but were detected by $\mathrm{MeOH} . \mathrm{K}_{v} 4.2$ is responsible for transient outward $\mathrm{K}^{+}$current, $\mathrm{I}_{\mathrm{to}}[10] . \mathrm{Ca}_{\mathrm{v}} 1.2\left(\alpha_{1 \mathrm{C}}\right)$ is responsible for L-type $\mathrm{Ca}^{2+}$ current, $\mathrm{I}_{\mathrm{CaL}}[10]$. For $\mathrm{K}_{\mathrm{v}} 4.2$, the labelling at the ID in myocytes with $\mathrm{MeOH}$ fixation in this study was similar to the one observed in a previous study in which $4 \%$ paraformaldehyde (PFA) was used as a fixative [1], but the labelling at the ID was not detected with 4\% FA fixation in our study. In both atrial and ventricular myocytes fixed with $2 \%$ PFA, $\mathrm{Ca}_{\mathrm{v}} 1.2$ was detected at the sarcolemma as a transversely striated pattern by immunofluorescence labelling [9]. These differences in the labelling pattern may be due to differing FA concentrations or differing primary antibodies being used. Like $\mathrm{K}_{\mathrm{v}} 1.5$ and $\mathrm{K}_{\mathrm{v}} 4.2$ at IDs and $\mathrm{Ca}_{\mathrm{v}} 1.2$ labelling at $\mathrm{t}$-tubules in the present results, if a particular protein is not detected using FA but is detected when $\mathrm{MeOH}$ is used, it is likely to be due to FA masking of the epitopes of antigens [6]. 
$\mathrm{K}_{\mathrm{ir}} 6.2$ at the $\mathrm{t}$-tubules and $\mathrm{Na}_{\mathrm{v}} 1.5$ at the sarcolemma were detected by FA but not by $\mathrm{MeOH}$ (Table 1 ). $\mathrm{K}_{\mathrm{ir}} 6.2$ is responsible for the ATP-sensitive inwardly rectifying $\mathrm{K}^{+}$current, $\mathrm{I}_{\text {KATP }}[10]$. $\mathrm{Na}_{\mathrm{v}} 1.5$ is responsible for the fast $\mathrm{Na}^{+}$current, $I_{\mathrm{Na}}$ [10]. $\mathrm{Na}_{\mathrm{v}} 1.5$ on IDs was similar to those fixed with FA reported in earlier studies [8]. The heteromultimeric complexes of sulfonylurea receptors (SUR) and $\mathrm{K}^{+}$inward rectifier $\left(\mathrm{K}_{\mathrm{ir}}\right)$ gene products were suggested to form sarcolemmal channels [11]; however, the subcellular localisation of $\mathrm{K}_{\mathrm{ir}}$ has rarely been found. In this study, $\mathrm{K}_{\mathrm{ir}} 6.2$ was only detected as possessing a transversely striated pattern. Like the case of $\mathrm{K}_{\mathrm{ir}} 6.2$ at the t-tubules and $\mathrm{Na}_{\mathrm{v}} 1.5$ at the sarcolemma in the present results, if a particular protein is not detected using $\mathrm{MeOH}$ but is detected using FA, this result is likely due to the effects of morphological alteration, such as altered antigen localisation in the cell membrane [13].

The fixation protocol was not affected to detect immnolabelling of $\mathrm{Na}_{\mathrm{v}} 1.1$ which is responsible for the slow $\mathrm{Na}^{+}$current, $\mathrm{I}_{\mathrm{Na}}[10]$ (Table 1). The labelling of $\mathrm{Na}_{\mathrm{v}} 1.1$ on t-tubules and the sarcolemma was similar to that in a previous study of fixation with FA [8].

\section{CONCLUSIONS}

Although FA alone has previously been used as a fixative for the immunofluorescent determination of the localisation of cytoskeletal ion channel proteins, it was shown to be insufficient from our observations. Therefore, we suggest that to optimise the detection of ion channels in cardiac cells by immunolabelling, both FA and $\mathrm{MeOH}$ fixation protocols should be used.

\section{ACKNOWLEDGEMENTS}

This study was supported by the British Heart Foundation, British Council and the Daiwa Anglo-Japanese Foundation.

\section{REFERENCES}

1. Barry DM, Trimmer JS, Merlie JP, Nerbonne JM (1995) Differential expression of voltage-gated $\mathrm{K}+$ channel subunits in adult rat heart. Relation to functional $\mathrm{K}+$ channels? Circ Res, 77: 361-369.
2. Dobrzynski H, Marples DD, Musa H, Yamanushi TT, Henderson Z, Takagishi Y, Honjo H, Kodama I, Boyett MR (2001) Distribution of the muscarinic $\mathrm{K}+$ channel proteins Kir3.1 and Kir3.4 in the ventricle, atrium, and sinoatrial node of heart. J Histochem Cytochem, 49: 1221-1234.

3. Dobrzynski H, Rothery SM, Marples DD, Coppen SR, Takagishi Y, Honjo H, Tamkun MM, Henderson Z, Kodama I, Severs NJ, Boyett MR (2000) Presence of the Kv1.5 K(+) channel in the sinoatrial node. J Histochem Cytochem. 48: 769-780.

4. Farmilo AJ, Ronald H (2001) Fixation. In: Boenisch T ed. Handbook Immunochemical staining methods. 3rd Ed. Dako Corporation, California, pp. 18-22.

5. French D, Edsall JH (1945) The reaction of formaldehyde with amino acids and proteins. Adv Protein Chemi, 2: 277-335.

6. Jamur MC, Oliver C (2010) Cell fixatives for immunostaining. Methods Mol Biol, 588: 55-61.

7. Lojda Z (1965) Fixation in histochemistry. Folia Morphol, 13: 65-83.

8. Maier SK, Westenbroek RE, Schenkman KA, Feigl EO, Scheuer T, Catterall WA (2002) An unexpected role for brain-type sodium channels in coupling of cell surface depolarization to contraction in the heart. P Natl Acad Sci USA, 99: 4073-4078.

9. Musa $\mathrm{H}$, Lei M, Honjo $\mathrm{H}$, Jones SA, Dobrzynski H, Lancaster MK, Takagishi Y, Henderson Z, Kodama I, Boyett MR (2002) Heterogeneous expression of $\mathrm{Ca}(2+)$ handling proteins in rabbit sinoatrial node. J Histochem Cytochem, 50: 311-324.

10. Opie LH (2004) Heart physiology from cell to circulation. 4th Ed. Lippincott Williams \& Wilkins, Philadelphia.

11. Seharaseyon J, Ohler A, Sasaki N, Fraser H, Sato T, Johns DC, O'Rourke B, Marban E (2000) Molecular composition of mitochondrial ATP-sensitive potassium channels probed by viral Kir gene transfer. J Mol Cell Cardiol, 32: 1923-1930.

12. Shui Z, Boyett MR, Zang WJ (1997) ATP-dependent desensitization of the muscarinic $\mathrm{K}+$ channel in rat atrial cells. J Physiol, 505: 77-93.

13. Smith-Clerc J, Hinz B (2010) Immunofluorescence detection of the cytoskeleton and extracellular matrix in tissue and cultured cells. Methods Mol Biol, 611: 43-57.

14. Yamanushi TT, Shui Z, Leach RN, Dobrzynski H, Claydon TW, Boyett MR (2007) Role of internalization of M2 muscarinic receptor via clathrin-coated vesicles in desensitization of the muscarinic $\mathrm{K}+$ current in heart. Am J Physiol Heart Circ Physiol, 292: H1737-H1746.

15. Yoo S, Dobrzynski H, Fedorov VV, Xu SZ, Yamanushi TT, Jones SA, Yamamoto M, Nikolski VP, Efimov IR, Boyett MR (2006) Localization of $\mathrm{Na}+$ channel isoforms at the atrioventricular junction and atrioventricular node in the rat. Circulation, 114: 1360-1371. 